\title{
"Puro preconceito! Vem de brinde com a bola!": o tabu da (homo)sexualidade em uma equipe de futsal feminino
}

\section{Resumo}

Este trabalho objetivou compreender as experiências educativas de praticantes de futsal feminino, com foco nas questões relativas ao gênero e à sexualidade, uma vez que o futebol ainda é um território de hegemonia dos homens. Para tal, realizou-se um estudo etnográfico com atletas de uma equipe universitária do interior paulista. Os resultados evidenciaram que as participantes sofreram uma série de discriminações ao longo de suas trajetórias na modalidade, associados às suas expressões de gênero e orientações sexuais. Diante da força coercitiva da heteronormatividade, a equipe fazia da homossexualidade um tabu. Concluiu-se que estas mulheres, simultaneamente, reproduziam e contestavam valores e atitudes relacionadas aos gêneros e sexualidades normativos. Por fim, evidenciou-se que o futsal assumia tal importância em suas vidas que as experiências vivenciadas constituiam parte de suas subjetividades.

Palavras-chave: Heteronormatividade; Gênero; Mulheres; Esportes; Experiência educativa; Etnografia.

\section{Introdução}

"Quando eu fui querer começar a treinar futsal", meu pai e minha mãe não queriam deixar, porque é coisa de homem! Eles não queriam deixar!' (Milena, em sua entrevista). A frase, pronunciada por uma de nossas interlocutoras de pesquisa, possivelmente poderia representar uma infinidade de meninas e mulheres Brasil afora.

Em nosso país, indubitavelmente, o futebol ocupa espaço de destaque na vida social da população: grande parte das atividades cotidianas são paralisadas em dias de Copa do Mundo, veículos de imprensa cobrem semanalmente muitas partidas de futebol, há grande quantidade de obras artísticas (cinema, teatro, pintura, música) retratando a modalidade ${ }^{1}$. Estes fatos nos permitem pensar o futebol como um fenômeno sociocultural por meio do qual é possível ver, analisar e compreender melhor a sociedade brasileira $^{1-3}$. O futebol é, portanto, uma forma de expressão que espelha "a própria sociedade, com todas as suas características e contradiçóes"1 (p. 120), "um veículo para uma série de dramatizaçôes da sociedade brasileira"3 (p. 21). O ato de dramatizar - destaca DAMATTA $^{3}$ - chama a atenção para relaçóes, valores ou ideologias que, de outro modo, não poderiam ser devidamente isoladas das rotinas que fazem parte $\mathrm{da}$ vida diária.

Porém o futebol (e seu derivado, o futsal) é, ainda, um campo masculino. Desde pequenos os meninos tendem a ser socializados no universo futebolístico. Já nos primeiros anos de vida muitos meninos brasileiros ganham uma bola para brincar. Depois, são levados para escolinhas de futebol, ou jogam nas ruas, nos clubes, nos pátios escolares. Tais oportunidades não costumam ser oferecidas com a mesma frequência às meninas. A socializaçáo do menino no universo futebolístico é tanto uma forma de reproduzir uma determinada masculinidade, heterossexual e hegemônica, como também de constituí-la. O futebol reflete o traço de masculinidade presente na própria sociedade brasileira ${ }^{1}$.

Sobre as meninas e mulheres que praticam o futebol/futsal recai uma série de dúvidas, preconceitos 
e estereótipos sobre seus gêneros e sexualidades. No linguajar cotidiano, de acordo com o Dicionário HouaIss da Língua Portuguesa ${ }^{4}$, por preconceito entende-se a opinião ou sentimento hostil concebido sem exame crítico, assumido em consequência da generalização apressada de uma experiência pessoal ou imposta pelo meio; ou, ainda, intolerância. Tais generalizaçóes, denominadas de estereótipos, correspondem à ideia ou convicção classificatória preconcebida sobre alguém ou algo, resultante de expectativa, hábitos de julgamento ou falsas generalizaçôes. Os estereótipos e os preconceitos geram discriminação. No que diz respeito à discriminação, trata-se do tratamento pior ou injusto dado a alguém por causa de características pessoais; isto é, de açóes motivadas por intolerância e/ou preconceito ${ }^{4}$.

Este estudo objetivou uma maior compreensão - por meio da descrição e análise - das experiências educativas que permeiam a prática do futsal feminino em uma equipe universitária. As seguintes questôes nortearam a pesquisa: de que modo a prática de futsal se insere no processo de socialização das praticantes? Como se apresentam/apresentaram nas experiências das praticantes, os preconceitos e estereótipos que historicamente permeiam o futebol feminino? As experiências de envolvimento com o futebol/futsal têm contribuído para a manutenção e reforço dos estereótipos e preconceitos de gênero e orientação sexual, ou para sua desconstrução? Em decorrência dessas experiências, houve mudança de atitudes e valores por parte das praticantes em relação ao futebol e às questóes de gênero e sexualidade que permeiam sua prática?

Partimos do entendimento de que, à medida que vive, o ser humano, inevitável e simultaneamente, realiza ou sofre experiências e aprendizagens. Experiência é algo que diz respeito a cada sujeito, é aquilo que se passa, acontece ou toca determinada pessoa, e que traz em si, como componente

\section{Método}

Foi realizado um estudo etnográfico com uma equipe universitária de futsal feminino do interior paulista. ROCKWELL ${ }^{9}$ aponta para alguns pontos comuns que definem a etnografia em contraste com outras formas de investigar, ou seja, algumas características sem as quais uma investigação não seria etnográfica:

a) O que o etnógrafo faz é documentar o nãodocumentado da realidade social; fundamental, a capacidade de formação ou de transformação 5 . O valor de uma experiência reside na percepçáo das relaçóes ou continuidades às quais ela conduz o indivíduo; neste sentido, aprende-se graças ao fluxo contínuo de experiências ${ }^{6}$. Na apreensão de TeIXeIRA ${ }^{7}$, para o eminente filósofo e educador John Dewey, uma experiência torna-se educativa quando, por meio da reflexão, se vem a perceber as relaçóes e continuidades antes não percebidas, alargando os conhecimentos e dando maior significação à vida.

A natureza da experiência só pode ser compreendida ao se considerar que esta encerra em si um elemento ativo e outro passivo. "Em seu aspecto ativo, a experiência é tentativa - significação que se torna manifesta nos termos experimento, experimentação que lhe sáo associados. No aspecto passivo, ela é sofrimento, passar por alguma coisa"6 (p. 152). Quando um indivíduo experimenta alguma coisa, age sobre ela, faz alguma coisa com ela; em seguida ela o faz em troca alguma coisa:

A experiência na sua qualidade de tentativa subentende mudança, mas a mudança será uma transição sem significação se não se relacionar conscientemente com a onda de retorno das consequências que dela defluam. Quando uma atividade continua pelas consequências que dela decorrem a dentro, quando a mudança feita pela ação se reflete em uma mudança operada em nós, esse fluxo e refluxo são repassados de significaçáo. Aprendemos alguma coisa ${ }^{6}$ (p. 152).

A valorização da continuidade da experiência é um dos pontos mais importantes da filosofia da Educação construída por John Dewey ${ }^{8}$ a a possibilidade de previsão resultante da continuidade da experiência é, no entanto, falível: "quando uma previsão efetuada não atinge um resultado satisfatório, o organismo, a partir desse erro, utiliza essa experiência vivida em situaçóes subsequentes" (p. 27).

b) O produto do trabalho analítico é, antes de tudo, uma descrição;

c) A centralidade do etnógrafo como sujeito social e sua experiência direta, prolongada, em uma localidade (na etnografia o pesquisador responsável pela coleta de dados obrigatoriamente é o responsável pela análise dos mesmos, este processo é indissociável);

d) A atenção aos significados (ou seja, tornar-se capaz 
de compreender a visão do grupo investigado);

e) $\mathrm{O}$ antropólogo constrói conhecimento.

Tais características fizeram da etnografia o método adequado frente ao objetivo delineado para esta investigação por nos permitir, por meio das "descriçóes densas" 10 provenientes do contato prolongado com o campo de pesquisa, alcançar uma maior compreensão das experiências educativas vividas pelas praticantes de futsal. A descrição densa, ao invés de uma "mera" descrição que acaba por constituir-se apenas em um relato de campo, corresponde ao desvelar de significados por trás das açóes, gestos e situações, apenas compreensíveis para aqueles que estão familiarizados com os signos do grupo social em questáo. Ou seja, exige a capacidade de interpretação, conforme explicitado no exemplo fornecido por Riley e reproduzido por Geertz: imagine dois garotos piscando rapidamente o olho direito. Num deles, este é um tique involuntário; no outro, é uma piscadela conspiratória a um amigo. Como movimentos, os dois são idênticos. Uma descrição superficial limitar-se-ia a descrever o movimento de ambos como uma rápida contração da pálpebra direita, enquanto a descrição densa possibilitaria a compreensão de que o primeiro garoto piscou porque tem um tique involuntário, enquanto o segundo piscou para comunicar uma conspiração a um amigo. Além disso, a piscadela poderia assumir outros significados. Poderia surgir um terceiro garoto e imitar o tique nervoso do primeiro, como forma de satirizá-lo. Novamente, o movimento de pálpebras seria o mesmo, mas a piscadela só seria eficiente se as pessoas para quem ele piscasse compreendessem se tratar de uma sátira. Esse mesmo terceiro garoto poderia, em casa, treinar em frente ao espelho sua imitação da piscadela. Nesse contexto, sua piscadela assumiria então um novo significado distinto dos anteriores (passaria a ser um treino, e não mais uma imitação $)^{10}$. A diferença entre descrições superficiais e descrições densas é que a primeira apenas descreve o observado, ao passo que a segunda realiza a descrição, mas se pauta pelos seus significados ${ }^{11}$, isto é, baseia-se na descrição e análise das situaçóes e/ou comportamentos observados.

Os dados foram coletados por meio de observação participante dos treinamentos e partidas oficiais, bem como por meio de entrevistas semiestruturadas com as participantes. A equipe era composta por 18 mulheres, com idades variando entre 19 e 24 anos e idade média de 21 anos, todas alunas ou ex-alunas da universidade em questáo. A maior parte das praticantes era oriunda do curso de Educação Física, que contabilizou 10 integrantes no grupo. Foram realizadas 46 idas a campo, durante um período de quatro meses. Destas, 32 ocorreram em treinamentos, 11 corresponderam a partidas oficiais (competições ou partidas amistosas) e 3 foram momentos festivos ou de encontros sociais do grupo ou parte dele.

A pesquisa foi devidamente aprovada pelo Comitê de Ética em Pesquisa da Faculdade de Ciências da Unesp de Bauru; atletas, treinador e a Universidade onde foi desenvolvida a etnografia tiveram seus nomes preservados em respeito ao atendimento da condição de anonimato, garantida pelo termo de consentimento livre e esclarecido para participação na pesquisa, assinado por todos(as) os(as) envolvidos(as) nesta investigação, incluindo a representante da Associação Atlética responsável pela equipe. Os nomes reais das atletas, bem como o nome de um atleta da equipe masculina que será mencionado nos relatos de campo, foram substituídos por nomes fictícios.

Os dados decorrentes da observação participante foram registrados em diário de campo escrito, bem como por meio de fotografias e vídeos. Foram realizadas entrevistas semiestruturadas com 13 atletas, registradas em gravador de voz e posteriormente transcritas para análise. Os dados foram interpretados através do diálogo com as questóes teóricas postas pela literatura.

\section{Resultados e Discussão}

Era por volta de onze horas da manhã daquela segunda-feira de maio quando adentrei em um dos prédios didáticos do curso de Educaçáo Física acompanhada de Helena. Lá, realizei a maior parte das entrevistas desta investigação. Sentadas uma de frente para a outra, ela e eu conversávamos, ao lado do pequeno gravador em funcionamento. Indaguei: "E você já viu alguma menina sofrer algum tipo de discriminação ou preconceito por jogar futsal?". Helena respondeu-me prontamente: "Foi uma das meninas mesmo, que a gente tava jogando, a gente tava ganhando, ai chegou um cara da arquibancada e falou: "éfutsal feminino, não émasculino", alguma coisa assim. Não sei se é porque ela jogava bem, ou se pelo jeito [mais masculino] dela".

Assim como exemplificado no excerto que inicia esta seção, a imersão em campo evidenciou que a 
quase totalidade das atletas da equipe investigada já havia sofrido algum tipo de discriminação por jogar futsal, relacionadas com suas expressóes de gênero e/ou orientaçóes sexuais, muitas vezes em situaçóes nas quais se estabeleceu uma relação direta e equivocada entre ambos. Ou seja, por praticarem uma modalidade esportiva considerada "masculina" (gênero), muitas vezes são consideradas, automaticamente, homossexuais (sexualidade). Tal ocorre porque estas jovens mulheres subvertem a lógica da matriz heterossexual ${ }^{12}$, isto é, a lógica que estabelece a expectativa social de que deva haver uma coerência linear entre sexo, gênero e desejo. Assim, por exemplo, se uma pessoa nasce com vagina, é considerada mulher, espera-se que exiba traços "femininos" e seja heterossexual - como se, para ser mulher e heterossexual, fosse necessário atender aos padróes de gênero hegemônicos na sociedade e se, para ser lésbica, fosse preciso ser masculinizada.

As experiências de discriminação relatadas foram vivenciadas por intermédio de falas ou atitudes de familiares, torcedores, de um treinador, uma vendedora e um médico, conforme se exemplifica nos excertos apresentados no QUADRO 1.

QUADRO 1- Relatos de discriminações vividas pelas atletas.

\begin{tabular}{|c|c|}
\hline \multicolumn{2}{|r|}{ Trechos das entrevistas } \\
\hline I & $\begin{array}{l}\text { Você vê direto, muitas pessoas questionam: “você joga futebol?”, e perguntam sua orientação sexual, sabe? Se eu falasse } \\
\text { que jogava vôlei, a pessoa nem pensa nisso. Mas no futsal você vê muito isso. Os meninos, aqui na faculdade, perguntam } \\
\text { (Paula). }\end{array}$ \\
\hline II & $\begin{array}{l}\text { Uma vez eu fui no ginecologista, contei pro médico que eu jogava futsal e ele simplesmente falou que eu tinha que parar } \\
\text { de jogar! Porque era um jogo muito masculinizado, e que eu ia poder me machucar, e tudo mais (Heloísa). }\end{array}$ \\
\hline III & $\begin{array}{l}\text { Uma vez cheguei no ginásio [com suas colegas de equipe] e ouvi um homem falando assim: “ó lá, filho, os molequinho } \\
\text { jogando!", entendeu? Chato! A sociedade é preconceituosa. (Milena) }\end{array}$ \\
\hline IV & $\begin{array}{l}\text { Quando eu fui comprar a chuteira era difícil encontrar o tamanho, o short também, e a vendedora falou: "Ah, mas você } \\
\text { joga futebol?", "Ah, jogo, num tem essa!". (Beatriz) }\end{array}$ \\
\hline $\mathrm{V}$ & $\begin{array}{l}\text { Minha mãe chegou pra mim esses dias e falou que ela sabe que meus parentes falam isso de mim, que eles acham que } \\
\text { sou homossexual, sabe? Porque eu jogo futebol, e que não sei o quê, sabe? Por diversos motivos, que eu não sei, eles } \\
\text { têm os motivos deles, né? E eles falam, entre eles, nas costas. Só que diretamente ninguém fala. Isso é incrível, sabe? } \\
\text { Ninguém chega pra você e fala na sua cara, ou te pergunta, "você é isso?” ou “você é aquilo?”. Não! Eles falam só nas } \\
\text { suas costas (Olívia). }\end{array}$ \\
\hline VI & $\begin{array}{l}\text { Tanta coisa! Preconceito por tudo! Não que as pessoas falem diretamente pra mim. Tipo, quando eu era pequena, } \\
\text { criança, sofri bullying [ri]. Quando eu era pequena me xingavam: "Maria João!", "sapatão!”. Tudo quanto é coisa eu já } \\
\text { ouvi, principalmente quando eu era pequena. Porque eu jogava no meio dos meninos. Não jogar, assim, eu brincava na } \\
\text { escola. Só que eu jogava vôlei com as meninas, depois eu ia pro futsal. Eu nunca jogava uma coisa só. Eu brincava com } \\
\text { todo mundo e depois ia lá. Aí no intervalo as crianças xingavam, zoavam, aí eu saia correndo atrás. Eu batia só o pé, } \\
\text { assim, porque eles zoavam, mas ao mesmo tempo tinham medo, porque sabiam que eu náo ia recuar. Entâo eles zoavam, } \\
\text { eu saia correndo. Sempre foi assim. Minha vida toda, desde pequena, me zoaram (Olívia). }\end{array}$ \\
\hline VII & $\begin{array}{l}\text { Ah, no começo quando eu fui querer começar a treinar futsal, meu pai e minha mãe não queriam deixar, porque "é coisa } \\
\text { de homem"! Eles não queriam deixar! Daí eu fui de frente e comecei a ir, mesmo. Não dei bola pro que eles falavam e } \\
\text { comecei a treinar. (Milena) }\end{array}$ \\
\hline VIII & $\begin{array}{l}\text { Nos jogos, por exemplo, os meninos falaram: "ai, você podia jogar com a gente, você é forte". Aí eu pensei e falei: } \\
\text { "nossa, só porque eu aparentemente tenho uma força assim a mais que as meninas do meu time, quer dizer que eu me } \\
\text { encaixaria num jogo de homem?”, sabe? Eu fiquei na dúvida disso. Será que eles estão falando, tipo, "ah, você é quase } \\
\text { um homem!", sabe? Eu me senti meio assim. Aí olhei assim [...]. E o treinador me falava: "não, você tem hormônio } \\
\text { masculino a mais, não é possível!". E eu já ouvi coisas assim, tipo: "Ah, você deve ter hormônio masculino", "você deve } \\
\text { tomar bomba”, coisas que nunca fiz, mas comparando com o que eles falam, sabe? Meio que tentando justificar: "se } \\
\text { você tem alguma coisa que alguns meninos têm - sabe? Tem alguns que não têm, também - é porque você toma alguma } \\
\text { coisa!". Tem esse preconceito. Se você tem algo mais perto da força masculina é porque você fez algo, sabe? Não é } \\
\text { natural, você deve ter feito alguma coisa pra tá assim. Entâo eu já ouvi isso, de comparação homem e mulher (Olívia). }\end{array}$ \\
\hline
\end{tabular}


QUADRO 1- Relatos de discriminações vividas pelas atletas.

\begin{tabular}{|c|c|}
\hline \multicolumn{2}{|r|}{ Trechos das entrevistas } \\
\hline IX & $\begin{array}{l}\text { Ah, agora nos [Jogos] Regionais que eu fui jogar lá em Dracena, o cara falou assim: "ah, é difícil acreditar que você joga } \\
\text { no gol, porque você tem um rostinho táo angelical, dá até medo de chutar em você e acabar machucando”! O auxiliar } \\
\text { técnico falou isso pra mim, entendeu? Daí eu falei assim: "nâo me julgue pela aparência!". Até a Olívia falou assim: "as } \\
\text { aparências enganam, e como enganam!", ela falou. Aí ele falou assim: "ah, mas você joga faz tempo?”, falei "eu jogo. Já } \\
\text { joguei Record, Tv Tem, vários Regionais, não sou menininha, patricinha, essas coisas assim bobinha, não. Não tem nada } \\
\text { a ver minha aparência com minha forma de jogar!". (Milena) }\end{array}$ \\
\hline $\mathrm{X}$ & $\begin{array}{l}\text { Eu estudei numa [cita o nome da escola], e lá as aulas de Educação Física eram: as meninas jogam handebol e vôlei, e os } \\
\text { meninos jogam futsal. E eu cheguei, acho que a professora nunca tinha tido uma aluna que queria jogar futsal. E ela nâo } \\
\text { queria de jeito nenhum que eu jogasse futsal! "Não, vamos jogar hand [handebol], vamos jogar hand!". }\end{array}$ \\
\hline $\mathrm{XI}$ & $\begin{array}{l}\text { Minha vó, minhas tias, são muito certinhas, na regra, sabe? Aí minha tia fala: "ai, isso é coisa de moleque, pára com } \\
\text { isso!", "Que coisa feia! Isso é coisa de moleque!". Só falam que é coisa de moleque. E meu vô fala que é coisa de sapatăo, } \\
\text { ele fala: "ô, sapatão!!" [para ela], zoando. E só. Minhas tias ficam zoando, falando que eu fico toda roxa, e que eu tenho } \\
\text { que parar com isso. (Carla) }\end{array}$ \\
\hline XII & $\begin{array}{l}\text { Nossa, já me chamaram de "sapatão" horrores porque eu jogo futebol! [ri]. Eu acho que isso vem de, nossa, de todos os } \\
\text { lados possíveis!! De família - pai, mãe, irmão. Hoje em dia eu sou um pouco mais crítica, mas eu não ligava tanto... "Ah, } \\
\text { isso é coisa de menino!" [diziam a ela]... "Parece um macho!" [ri], "você parece um macho com a bola!". (Samantha) }\end{array}$ \\
\hline XIII & $\begin{array}{l}\text { Meus tios iam brincar de bater bola com os meus primos, e eu entrava no meio. Aí eles falavam assim: "ai, mas é } \\
\text { menina..." Aí depois de um certo tempo eu ganhei autonomia nisso, entấo eu brinco e eles não falam nada, me } \\
\text { chamam pra brincar hoje em dia. Mas falam assim: "ah, pára que você joga! Você não sabe jogar!". Aí tinha um tio meu } \\
\text { que jogava futsal, jogava muito bem, e eu sempre falava "me leva, me leva", e ele nunca me levou! Falava que eu era } \\
\text { uma menina e não ia jogar com um monte de cara lá. Mas eu sentia que era por preconceito com meninas e tal. Puro } \\
\text { preconceito! Vem de brinde com a bola! (Samantha) }\end{array}$ \\
\hline XIV & $\begin{array}{l}\text { Uma vez eu tava saindo de casa, e minha mãe falou assim: "onde você vai?". "ah, mãe, tô indo treinar". Aí ela falou } \\
\text { assim: "Ai, vai lá naquele meio de sapatấo treinar? Fica em casa, não vai treinar, não!". (Helena) }\end{array}$ \\
\hline
\end{tabular}

Compreender esses depoimentos exige que se faça uma breve retomada histórica sobre a participação das mulheres no universo esportivo, notadamente, uma área de reserva masculina ${ }^{13-16}$. O próprio conjunto de adjetivos tradicionalmente utilizados para caracterizar o esporte refletem características que representam o mundo masculino (com referência a um modelo masculino hegemônico): força, determinação, resistência e superação de limites ${ }^{17}$.

"A hegemonia ideológica do esporte, enquanto instituição masculina, invalidou a experiência atlética como uma busca feminina digna” e, como consequência, as mulheres foram tidas, por muito tempo, como invasoras de um espaço masculino ${ }^{17}$ (p. 50). Exemplo disso foi sua exclusão pelo idealizador dos Jogos Olímpicos Modernos, Barão Pierre de Coubertin, nos primeiros jogos, em 1896. Às mulheres coube apenas a posição de espectadoras. Isso fez com que a participação masculina nos jogos fosse legitimada como um fenômeno natural, 
bastando para tal que os homens apresentassem habilidades suficientes para a competição, enquanto a participação feminina era vista como uma anomalia ${ }^{17}$. Entre os argumentos utilizados para a exclusão feminina encontravam-se "a 'delicadeza' dos nervos e a constituição física menos favorecida, o que levava o esporte praticado por mulheres a parecer indecente, feio e impróprio para sua resistência" ${ }^{\text {"17 }}$ (p. 53). As mulheres começariam a participar apenas a partir do evento olímpico seguinte, em 1900, em uma Paris marcada pelo liberalismo, que aceitaria sua participação, mas restrita ao golfe e ao tênis, modalidades que não ofereciam contato físico e eram consideradas esteticamente belas ${ }^{17}$.

Já a inserção das brasileiras no mundo esportivo iniciou-se em meados do século XIX, e adquiriu maior importância e visibilidade à partir das primeiras décadas do século $\mathrm{XX}^{18-19}$. A estrutura extremamente conservadora da sociedade na primeira metade do século XIX não permitia a participação das mulheres em muitas esferas sociais, dentre as quais se incluía a esportiva, já que elas eram criadas para serem esposas e mães. Homens e mulheres da elite estavam separados na distinção entre o público e o privado, respectivamente; o patriarcalismo permeava toda a organização da sociedade ${ }^{19}$. Já na segunda metade do século XIX, após a independência do Brasil, o discurso dos médicos higienistas, somado à construção de um projeto nacional de engrandecimento da naçáo, passam a ditar normas de comportamento para homens e mulheres em nome da educação moral, física, sexual e social. Às mulheres eram indicadas formas de comer, de se vestir, de falar, de trabalhar, de se embelezar, de se movimentar, de se comportar. Dentre tais prescriçóes, uma era considerada fundamental: a prática de exercícios físicos direcionados à preservação e constituição de uma boa maternidade, considerada a mais nobre missão da mulher ${ }^{18}$. As mulheres eram identificadas como de natureza frágil, e circulavam vários discursos alertando para os possíveis perigos que a prática competitiva poderia lhes acarretar (lógica higienista), dentre eles, o risco da masculinização:

O suor excessivo, o esforço físico, as emoções fortes, as competiçóes, a rivalidade consentida, os músculos delineados, os gestos espetacularizados do corpo, a liberdade de movimentos, a leveza das roupas e a seminudez, práticas comuns no universo da cultura física, quando relacionadas à mulher, despertavam suspeitas porque pareciam abrandar certos limites que contornavam uma imagem ideal de ser feminina. Pareciam, ainda, desestabilizar o terreno criado e mantido sob domínio masculino cuja justificativa, assentada na biologia do corpo e do sexo, deveria atestar a superioridade deles em relação a elas $^{18}$ (p. 92).

Com base neste temor, foi elaborado o DecretoLei no 3199, do Conselho Nacional de Desportos, de 14 de abril de 1941, segundo o qual "deve ser terminantemente proibida a prática do futebol, rugby, polo, water polo, por constituírem desportos violentos e não adaptáveis ao sexo feminino"18 (p. 93). As mulheres também ficaram oficialmente impedidas de praticar outras modalidades, tais como o boxe, outras lutas, o salto com vara, o decatlo e o pentatlo ${ }^{18}$. Tal proibição somente foi revogada em $1979^{14-18}$.

Foram argumentos assim, biologicistas, que ao longo da história justificaram a exclusão das mulheres do âmbito da Educaçáo Física e do esporte ${ }^{20}$. Resquícios que, todavia, continuam presentes na fala do médico de Heloísa (excerto III), que chegou a recomendar que a atleta interrompesse a prática de futsal, afirmando que ela poderia se machucar, já que a atividade seria própria apenas para o sexo masculino.

Raciocínio semelhante ao do médico é o que se vê na fala do auxiliar técnico diante do "rostinho angelical" de Milena (excerto IX): analisando os traços físicos da atleta (os quais associou a um padrão hegemônico de feminilidade), ele logo concluiu que ela aparentava ser frágil e inapta para jogar no gol, já que mulheres supostamente delicadas, não serviriam e nem saberiam jogar esse esporte socialmente considerado masculino.

Por outro lado, Olívia, exibindo uma força física além do que esperavam para seu sexo, sofreu o preconceito às avessas (excerto VI): se era uma atleta forte, então deveria jogar com homens, foi considerada um "quase" homem. Além disso, dizer que a atleta estava apta a jogar de igual para igual com os homens, usando o futsal masculino e o desempenho de seus jogadores como fator de comparação e meta a ser atingida, é também uma forma de legitimar este território como território masculino, como se o bom futsal fosse o futsal dos homens. Conforme constatou KessLeR ${ }^{21}$ (p. 51), "espera-se que as mulheres joguem da mesma forma que os homens, e quando estas jogam como eles, são taxadas como imitadoras, como cópias, ou então suas feminilidades são questionadas". Entende a autora que as mulheres que se sobressaem na modalidade, ao invés de receberem incentivos, são vítimas de discursos pejorativos ou discriminatórios. 
Conforme já mencionado anteriormente, em boa parte dos relatos (excertos I, VI, XI, XII e XIV) evidencia-se também a associação recorrente entre a prática do futsal, modalidade socialmente considerada masculina, e a suposta homossexualidade das mulheres que o praticam. Merece destaque a atitude de Paula (excerto I) que, refletindo diante dos preconceitos existentes na sociedade brasileira para com a modalidade, deixou claro que não aceita passivamente posicionamentos preconceituosos de seus colegas:

Acho que o futsal tá bem focado, sempre vai ser foco, não tem como. Porque 'futebol é coisa de menino', você aprende desde criança. Então, quem gosta de jogar futebol e não vê problema nisso tem que ter paciência pra ouvir. E talvez ter que se explicar sempre, falar: 'não, não é assim, é futsal'. [...] É aí que tá, me incomodar não incomoda nem um pouco, porque pra mim são dois pontos, aliás, mais que dois pontos. O primeiro é que faço psicologia, então... Pra mim, vir gente com discurso homofóbico pra cima de mim é pedir pra ouvir! Bem sinceramente, eu sou chata e falo: 'então vamos lá, vamos conversar sobre isso'. A pessoa toca no assunto e quer cutucar do lado dele, então vou cutucar também! Eu entro no assunto a fundo. E acho que pelo fato de que também eu sou muito aberta quanto a isso, sabe? Eu sou bem resolvida comigo e com o outro, assim. Se alguém vier falar... 'Ah, então, beleza, ache o que você quiser, sabe?' [indaga Paula] 'Ah, mas fulana é [homossexual]?' [perguntam os conhecidos], 'Cara, pergunta pra ela! Porque você tá perguntando pra mim?' [responde ela].

Raquel (excerto $\mathrm{X}$ ) é outra que não permitiu que uma situação na qual se sentiu discriminada por ser mulher e não poder praticar futsal transcorresse sem reação. A situação descrita envolvia a negativa da professora de Educação Física de sua escola em oferecer a modalidade futsal às meninas:

Eu falo pra minha mãe até hoje, acho que fui a primeira aluna que enfrentou ela, porque eu queria jogar futebol, e ela não aceitava! Aí com o tempo ela foi deixando, algumas meninas também começaram a jogar, a gente jogava. Aí, assim, menina que joga futebol os meninos sempre chamam, aí no intervalo eu jogava com os meninos, e aí ela foi acostumando com a ideia de ter uma menina que jogava futebol. Acho que no segundo ano eu fui pedir pra ela pra gente participar do Intercolegial, sabe? Ahh, pra quê? Foi um absurdo! Ela não queria que a gente participasse! [...] Aí eu chamava as meninas da sala também, e ela falava que não sabia se ia ter, aí eu fui falar com a diretora! Eu fui e falei: 'por que os meninos vão jogar futsal e as meninas vão jogar hand no intercolegial?'. Aí a diretora conversou e ela deixou montar o time. A gente foi campeão nesse ano!'.

Nas entrevistas realizadas ao longo da imersão etnográfica, citei três frases que circulam amplamente na sociedade brasileira acerca do futebol/ futsal feminino, e pedi às atletas que emitissem suas opinióes a respeito delas: "Mulher não sabe jogar futebol", "Futebol é coisa de homem" e "Toda mulher que joga futebol é homossexual". Em geral, minhas interlocutoras discordaram e argumentaram contra tais frases, as quais entenderam como preconceitos construídos historicamente. Porém, em sua maioria, concordaram que muitas das praticantes das modalidades são, de fato, homossexuais. Os relatos a seguir exemplificam as impressóes das atletas:

Ah, ridículo isso! Hoje em dia eu vejo mulher jogando melhor que muito homem. Igual na minha sala, de psicologia, os caras são um bando de perna de pau! É muito engraçado quando eles falam: "Vamos jogar? Mas a Paula não vale! Não sei o quê!”. Eu acho que é igual falar que mulher não sabe dirigir, não é a mulher, tem pessoas que sabem e pessoas que não. No sentido de que é a pessoa, não importa o sexo, então é balela total. São coisas que são construídas historicamente, conceitos que vão passando de geração em geração. E, realmente, não tô dizendo que é, mas é mais de homem, com certeza, na maioria. Só que aí você fala de Brasil, e vai descobrir que nos Estados Unidos é coisa de mulher! Entendeu? É muito cultural isso. Aqui no Brasil infelizmente e tenho que concordar com essa frase. É, é coisa de homem, no Brasil (Paula).

Eu acho que isso é só no Brasil. Por exemplo, nos Estados Unidos é um esporte feminino, entendeu? É ao contrário do nosso. Pra mulher! [...] Eu acho que tem muitas pessoas homossexuais que jogam futsal feminino. O problema é que também tem no time de vôlei, também tem em time de handebol. Só que assim, eu acho que isso vem com o tempo, porque o futsal feminino normalmente costuma ser o mais masculinizado, entendeu? Por isso que a gente ficou com essa certa fama, digamos assim. Eu acredito que é por causa disso. Porque nos outros 
esportes também tem. Eu acredito que durante os anos começou a ser uma coisa assim, tipo, como tem muita gente homossexual no grupo, começou a ser um jeito de você encontrar as pessoas que são homossexuais também (Heloísa).

Ah, eu acho que é quem não conhece, mesmo, quem é, sei lá, não tem a ver, por que mulher não pode jogar? Entâo vai falar que vôlei é coisa de menina, também? Entendeu? Mulher pode jogar, tem a mesma capacidade que os homens. Historicamente só que, né? Que o homem tem mais história, e tal, mas não significa que a mulher não pode jogar! [...] Eu acho que náo tem nada a ver. Mas, por exemplo, eu conheço meninas que são [homossexuais], e que querem jogar futebol, porque acham que sapatão tem que jogar futebol, entendeu? Entấo às vezes acaba tendo mais menina sapatão [ri da expressão que usou] pra jogar e o time fica com essa cara, porque... Mas acho que não influencia, o futebol não influencia (Marisa).

As falas de Heloísa e Marisa apontam para o futebol como espaço de socialização de mulheres lésbicas, entendimento corroborado por outros estudos empíricos, tais como o de Silveira ${ }^{22}$. No entanto, ainda que as atletas - entre concordâncias e discordâncias - tenham considerado as frases preconceituosas, o acompanhamento do cotidiano da equipe evidenciou situaçóes em que elas se contradisseram a partir de condutas e frases que inferiorizam o futsal feminino e, com isso, ajudam a legitimar o futsal como espaço masculino, como se observa nos relatos das situaçóes registradas em meu Diário de Campo:

Fábio [atleta da equipe masculina] está jogando em um dos times, para completar ao número de atletas. Ele erra várias jogadas. Samantha pergunta, irônica: "O Fábio vai jogar?”. Flávia responde, brincando: "O Fábio não tem vaga nem no feminino!”. Fernanda ouve, ri e conta para Marisa, que também acha graça (Diário de Campo, 25/04/2012).

Em um determinado momento, Fábio deu um passe muito rápido (forte) para Helena e ela não conseguiu acompanhar (correr em direção à bola, que ele havia lançado em profundidade). Ele pediu desculpas a ela, e ela disse que ela é que não tinha ido na bola. Samantha, do gol, exclamou: "São menininhas, Fábio!" (Diário de Campo, 09/05/12).
Além disso, as posiçóes do futsal (pivô, alas, fixo) foram sempre mencionadas com flexão de gênero no masculino - pelas atletas e pelo treinador - durante os treinamentos e partidas oficiais, ainda que fossem ocupadas por mulheres, comunicando, nas entrelinhas, que a modalidade não é destinada a elas. Tal parecia passar despercebido por todas as participantes e pelo treinador, que pareciam não se dar conta ou não se importarem com o uso das expressóes no masculino, indicando o quão naturalizada é esta atitude em suas falas: "Fulana, vocêfaz o pivô!", "eu jogo de fixo!".

Outra característica da equipe investigada que colaborava para a legitimação da modalidade como universo de dominação masculina era o hábito do treinador de, constantemente, utilizar a equipe masculina da Universidade - da qual também era treinador - como base de comparação para o desempenho da equipe feminina. Tais comparaçóes, em si, não as desmereciam ou inferiorizavam, mas evidenciavam a necessidade de deixar claro que havia diferenças fundamentais entre o futsal feminino e o futsal masculino. Tal atitude também passava despercebida por todas, que ouviam as comparaçóes com muita naturalidade, sem demonstrar qualquer tipo de incômodo.

Como apontado por Goellner ${ }^{14}$, por vezes há atletas que "moldam-se aos padróes masculinos de modo a náo questionar nem os preconceitos, nem as regras que o regem, expresso em atitudes, piadas, comportamentos, posturas corporais e discursos" (p. 149). É exatamente o que ocorria na equipe em relação às expressóes e opinióes relativas ao futsal (sempre citadas com flexão de gênero no masculino), às brincadeiras das atletas com Fábio, e na falta de percepção das comparaçóes constantes que o treinador insistia em fazer entre elas e a equipe masculina da Universidade.

A comparação entre os desempenhos de homens e mulheres no futsal, ou no futebol de campo, é algo comum na sociedade brasileira. Algo tão naturalizado que parece normal ou inofensivo. Jornalistas e narradores esportivos não hesitam em escrever em suas matérias, ou declarar em suas narrativas sobre a seleção brasileira feminina de futebol, afirmaçôes como "Fulana joga melhor que homem", ou que "Beltrana poderia jogar em qualquer time masculino!”. Tais posturas, preconceituosas, deixam implícito que o futebol praticado por mulheres é inferior ao praticado por homens e que, portanto, futebol é, mesmo, “coisa de homem”. Porém, por 
estarem tão cristalizadas e naturalizadas em nossa sociedade, não são sequer percebidas pela maior parte dos homens e mulheres, que veem tais comparaçóes como inofensivas e até mesmo lisonjeiras às mulheres que têm seus desempenhos igualados aos masculinos.

Em comparação a este passado relativamente recente, a participação feminina no universo esportivo é hoje muito mais ampla e diversificada. Mas isso "náo significa afirmar que homens e mulheres tenham as mesmas oportunidades no campo esportivo ou que preconceitos quanto à participação feminina inexistam" ${ }^{18}$ (p. 96). Embora a evolução das mulheres no esporte seja admirável, elas ainda vivem à sombra de muitos preconceitos sexistas ${ }^{15}$. "Contudo, se a pouca participação das mulheres nos esportes em geral é explícita, pode-se afirmar que a ausência delas nos esportes socialmente considerados masculinos torna-se mais evidente" 22 (p. 34-35). Por esportes socialmente considerados masculinos, Silveira ${ }^{22}$ entende as modalidades esportivas que, em determinada sociedade, são reconhecidas como reservadas aos homens: "Ou seja, não são esportes que as mulheres não praticam, ou que não estão adequados para elas, apenas são reconhecidos na sociedade como masculinos" (p. 35). Como exemplos de esportes socialmente considerados masculinos na sociedade brasileira, é possível citar o futebol e seus derivados, as lutas, o skate, o halterofilismo, entre outros. Preconceitos e estereótipos são comumente atribuídos às mulheres que praticam tais modalidades ${ }^{15}$.

O futebol feminino brasileiro exemplifica bem como ainda não são iguais as condiçôes e oportunidades de homens e mulheres no esporte ${ }^{18}$ : o número de mulheres brasileiras que praticam o futebol em clubes ou espaços de lazer aumentou em comparação às últimas décadas. No entanto, os campeonatos regionais e nacionais são poucos, e por vezes de realização incerta, e não há um número considerável de mulheres nas comissóes técnicas dos clubes, ou ao nível administrativo. Também é mais difícil encontrar "escolinhas" de futebol que contemplem as meninas, e é menor o oferecimento do futebol como atividade de lazer para mulheres.

Constatamos, na presente investigação, que uma série de preconceitos e estereótipos ainda rondam a prática modalidade por mulheres, tais como sua associação à homossexualidade e aos perigos que este esporte de contato supostamente ofereceria para suas saúdes reprodutivas. Dados similares foram encontrados em boa parte dos estudos sobre o futebol/futsal feminino no país ${ }^{21,23-27}$.
Surpreendentemente, durante o período em que foi realizada a observação de campo, a ocorrência de episódios envolvendo algum tipo de alusão à orientação sexual das atletas e/ou preconceitos associados a ela foram bastante raros. Porém, os relatos de duas das atletas denunciaram que a equipe vinha sendo alvo de preconceitos recorrentes:

Eu só ando com caras, ando com sete caras, desde que estou aqui [na Universidade], sabe? E eles me tratam como se eu fosse um irmão deles. O que eles mais falam na vida é zoar o futsal feminino! 'É vôlei masculino, futsal feminino' [cantarola, imitando amigos] - vôlei masculino é viado, futsal feminino é lésbica. Só isso que falam! Todos os lugares. [...] 'Pe pe tcha no grelo [denominação vulgar do clitóris], pe pe tcha no grelo'. É uma dança, é terrível! Aí eles começam: 'Carla, Carla, pe pe tcha no grelo, pe pe tcha no grelo!', o dia inteiro. (Carla).

Preconceito tem. O pessoal fala bastante da gente, o pessoal da faculdade. E uma vez uma amiga minha tava no vestiário, aí ela ouviu e veio depois me falar: 'ah, você vai lá treinar com as sapatão do futsal?', a menina virou e falou assim. Da Educação Física, mesmo. Aí ela veio e falou pra gente, sabe? Aí eu falei pras meninas. [...] Ah, elas ficaram bravas! Elas não gostaram! Porque até então essa menina estudava com uma delas, sabe? Ia no meio, ia pra festa junto, cervejada, e mesmo assim [...], os meninos mesmo, do futsal, comentam da gente, sabe? Tem um preconceito muito grande (Helena).

Após contato prolongado com a Equipe, constatei que temas como sexualidade, feminilidade, masculinidade, estereótipos e preconceito jamais eram abordados entre as praticantes. Nunca houve qualquer menção sobre homossexualidade feminina no âmbito grupal, nem positiva, nem negativa. Esta situação contrasta com os próprios relatos individuais de várias das atletas da Equipe, decorrentes de suas experiências em outras equipes de futsal feminino, nos quais a temática da sexualidade era recorrentemente abordada por atletas e treinadores, inclusive em virtude dos preconceitos relacionados à prática do futsal e à homossexualidade. De qualquer modo, a Equipe investigada não deixou de ser alvo de preconceitos na Universidade, tal como se pôde observar nos relatos das atletas apresentados anteriormente.

Buscando compreender o porquê da temática da orientação sexual não ter sido abordada pelo grupo 
sequer uma vez durante a observação participante, bem como a possibilidade de que talvez tal assunto fosse até mesmo evitado - impressão que a imersão no cotidiano da equipe me causava até então - indaguei às entrevistadas:

"Qual espaço você considera que a questão da orientação sexual ocupa neste grupo?”. Todas foram unânimes em afirmar que esse não era um assunto discutido coletivamente na equipe. Parte das atletas justificou tal situação afirmando que esta discussão seria irrelevante, em virtude de todas se respeitarem naquele contexto, independentemente de suas sexualidades. Também destacaram que o foco era jogar futsal, e a sexualidade não influenciaria nisso, conforme exemplificado no relato abaixo:

Vou tentar comparar os dois grupos que eu jogava. Por exemplo, o que eu jogava, eu sabia que tinha muitas meninas que eram [lésbicas], e tudo mais, então era uma coisa mais aberta, por exemplo: "ai, vamos respeitar mais”, sabe? Aqui não tem essa [...], é... Essa postura aberta sobre a nossa sexualidade, entendeu? Ninguém fala nada, ninguém comenta nada, nunca é um assunto aberto dentro do grupo. Sempre fica, assim, é, jogado alguns papos, sabe? Mas não é um assunto aberto. E a postura do time, ao meu ver assim, nunca teve nenhuma relação com isso. A postura nos treinos, você nunca escutou sobre isso. Mesmo nas reunióes que a gente faz, nunca... Churrasco, tipo assim, essas coisas, nunca é um assunto falado em equipe, né? Nesse grupo em específico eu acredito que não tenha diferença nenhuma, entendeu? Falar ou não falar sobre isso é irrelevante, a gente tá aqui por outros motivos, são outros objetivos, então até hoje não foi nenhum problema falar ou não falar sobre isso, então não tem problema, entendeu? Continuamos assim, continuamos treinando e jogando, não tem problema nenhum! (Heloísa).

No entanto, esta não era uma opinião unânime entre as atletas. Ainda que, de fato, a questão da orientação sexual não tenha gerado problemas ou conflitos no grupo, houve quem entendesse que a (homo) sexualidade não era assunto abordado não por ser irrelevante, mas sim por sua demasiada relevância: "Eu acho que elas tentam não discutir. É meio que aquela coisa, se você não discute, não há, não existe. Sabe aquela coisa de que o que os olhos não veem, o coração não sente?"(Olívia).

No decorrer da entrevista, a participante complementou sua opinião:

Olívia - Assim, na verdade acho que é a imagem que quem tá dentro quer passar. Eu acho que é isso. Quem tá dentro quer passar essa imagem de que todas são hetero.

Pesquisadora - Por quê?

Olívia - Eu acho que por medo do preconceito. Eu penso assim. Eu mesma, na faculdade, não falaria, entendeu? Ninguém saberia. Nem elas. [...] Então eu acho que é um certo receio de saberem. Apesar que ninguém chegou e perguntou. Se alguém chegasse $e$ perguntasse alguma coisa, eu falaria. Eu responderia.

Outras atletas também entenderam a não abordagem da temática como um tabu, como explicitado, por exemplo, por Paula:

Acho que não aparece, nem um pouco. Pelo menos comigo, nunca apareceu. Nunca ninguém questionou. Aliás, teve aí, né? No sentido de que tem meninas que tem a orientação de serem gays mesmo - e eu não tenho nenhum problema com isso -, e chegam em você e querem saber também. Então [ri] já chegaram do time tipo, querendo "me pegar", vamos dizer. Mas só nesse sentido que eu fiquei sabendo, assim. Quando a pessoa chegou eu falei: 'Opa! Calma'. Nesse sentido só. Mais de uma vez. Mas em uma conversa aberta, tipo um churrasco, ou em treino, uma coisa aberta assim, nunca, nunca vi. [...] Eu acho que é um tabu! Eu acho que é um tabu ainda no time. Entáo, na verdade, eu acho que as pessoas no time náo interagem o bastante pra serem íntimas nesse sentido.

Além disso, existia uma preocupação, por parte de alguns atletas em afirmar que não havia lésbicas na equipe, ou melhor, em afirmar a equipe como predominantemente formada por mulheres heterossexuais, ainda que a convivência prolongada com o grupo e os relatos de outras atletas tenham mostrado que havia uma parcela considerável de mulheres que se relacionavam com mulheres no grupo. $\mathrm{O}$ excerto a seguir explicita o discurso de negação da homossexualidade na equipe:

Quando eu entrei, tipo assim, primeiro treino, eu já vi que todas não curtiam [mulheres], daí já me associei com aquele grupo, né? Tipo, não que eu tenha preconceito com quem é [lésbica]! Com tanto que me respeite, tá bom! Aí quando fulana chegou, eu já percebi que só ela ali era [lésbica]. Que eu acho, que eu sei. Que aparenta ser, só ela”. (Milena). 
Enquanto algumas negaram a homossexualidade na equipe, outras insistiram em afirmar sua existência:

Oitenta por cento do time de futsal [da Equipe] é [lésbica]! [...] Eu acho que todo mundo que tá na equipe já sabe também, quem é, quem não é. Acho que isso não influencia em nada. Festa, isso que eu tô falando pra você é porque é onde eu mais encontro a galera. É normal. A galera que é sabe quem é, e, sei lá, se pegam aí. Mas, normal. No time ninguém comenta nada, a galera brinca, todo mundo conversa com todo mundo (Carla).

Tem umas meninas desse grupo que são [lésbicas], não falo que são assumidas pra Universidade, não gritam 'eu sou', mas quem convive mais com elas sabe! Por meio de, sei lá, grupo social, sair, então acaba descobrindo e sabe disso. Outras, você fica na dúvida! [ri] Porque não faz questão nenhuma de falar, mas também não afastam a ideia. E outras ainda fazem questão de falar que não! Assim, ninguém fala explicitamente, claramente, mas mostra, faz tudo pra mostrar que não [é lésbica] - mas que você não póe a máo no fogo mas nem ferrando! (Samantha).

Samantha e Olívia foram as únicas que optaram por se identificar à pesquisadora como lésbicas em suas entrevistas, ainda que náo o tenham feito explicitamente para a equipe. De qualquer forma, o fato de a orientaçáo sexual ser um tabu náo significa que as participantes não aceitassem as orientaçóes sexuais umas das outras. Pelo contrário, tal tabu não impedia que agissem de forma natural, espontânea e amistosa entre si. A sexualidade como tabu, ou seja, a opção de boa parcela do grupo pela invisibilidade de suas orientaçóes sexuais, levou todos(as) a crerem que a equipe - ou ao menos a maior parcela dela - fosse heterossexual, sobretudo para evitar discriminações, originadas muito provavelmente por outras pessoas, que não suas colegas de equipe: por seus pares na Universidade, suas famílias, seus amigos(as) e talvez até mesmo pelo treinador.

Ficou evidenciada a força coercitiva que a heteronormatividade - especialmente a heterossexualidade compulsória - exercia no contexto estudado. A heteronormatividade diz respeito às normas sociais que impóem não apenas a heterossexualidade em si, mas seu modelo a outras relaçôes, inclusive entre pares homossexuais ${ }^{26}$. Ainda que muitas das atletas se relacionassem com outras mulheres, elas se sentiam implicitamente pressionadas a se deixar ler como heterossexuais, atendendo às expectativas sociais do contexto em que viviam.

Minhas interlocutoras, no geral, não destoavam muito do estereótipo de feminilidade hegemônica: eram mulheres jovens e belas; com musculatura levemente definida e lida como sensual segundo o modelo de feminilidade hegemônico em nossa sociedade; possuíam cabelos compridos e bem cuidados; brincos e piercings. Em geral, a quase totalidade das atletas optava por ir aos treinamentos vestindo shorts justos, de lycra, que aderem ao corpo, ou entâo shorts soltos, porém curtos. A opção por tal vestimenta ao invés do uso dos calções mais largos e compridos, típicos do futsal, chama a atenção, uma vez que os códigos e símbolos do esporte espetáculo se faziam bastante presentes nos treinamentos: todas jogavam com tênis próprios de futsal e boa parte delas também vestia “meióes", muitas vezes levantados até a altura dos joelhos, como nas partidas oficiais. Neste sentido, não usar calções de futsal parecia ser uma forma de buscarem se aproximar mais dos padróes de feminilidade.

Essa preocupação não as impediu de jogarem com "garra”, se esforçarem ao máximo e inclusive demonstrarem força e resistência à dor, características que são associadas ao padrão de masculinidade hegemônico na sociedade. Assim, as condutas das atletas da equipe sinalizavam em uma direção: queriam provar-se capazes de jogar firme e bem, mas sem que parecessem "masculinizadas", e sem que isso fosse associado às suas orientaçóes sexuais. O silêncio sobre suas sexualidades era uma estratégia para evitar discriminações.

Abusca por corresponder ao padrão defeminilidade hegemônico, associado à heterossexualidade, também foi encontrada por Borges et al. ${ }^{16} \mathrm{em}$ praticantes de uma "escolinha” de futebol. Os autores entenderam tal postura como parte de seus comportamentos resilientes diante das dificuldades encontradas para a prática da modalidade, entre as quais o preconceito. No entanto, entendemos que encaixar-se no padrão heteronormativo que a sociedade espera e deseja, como estratégia para minimizar as situaçóes de preconceito, não deixa de ser também uma forma de aceitar, submeter-se e reforçar padróes de gênero e sexualidade.

Em suma, os dados das entrevistas evidenciaram que, no entendimento das atletas, suas principais aprendizagens (mudança de atitudes e valores) a partir da prática do futsal tangenciavam temáticas relacionadas ao respeito ao próximo e à superação 
do preconceito com homossexuais. As interlocutoras acreditavam que, ao conviverem com grupos heterogêneos no futsal, entrando em contato com pessoas de diferentes classes sociais, etnias, sexualidades, religióes, dentre outros marcadores sociais, tornaram-se mais tolerantes, pacientes e respeitosas com as diferenças.

Os dados da observação participante mostraram aproximaçóes e afastamentos para com estes discursos: se por um lado havia o respeito pelas pessoas homossexuais, diante da força coercitiva da heteronormatividade, a equipe fazia da (homo) sexualidade um tabu. Tal situação ilustra a busca das participantes pela modificação de hábitos diante das condiçóes novas que se apresentam por meio do fluxo e refluxo da experiência, conforme previsto por DEWEY 6 .

É importante destacar como as atletas se utilizaram de suas experiências para responder às questóes das entrevistas. Em diversos momentos elas recorreram ao que haviam realizado ou sofrido no futsal para formular suas respostas e analisar os preconceitos que incidem sobre a modalidade, tal como destaco, a título de exemplo, nos seguintes excertos: "igual na minha sala...", "minha vida toda...", “eu já ouvi...”, "vou tentar comparar os dois grupos em que eu jogava", "conheço meninas que são...", "o pessoal fala bastante da gente". Ficou evidente que as atletas vivenciaram o futsal para além de uma mera atividade - definida por Dewey como dissipadora, dispersiva e centrífuga ${ }^{6}-$ mas como experiência, na qual afetaram e foram afetadas pela prática da modalidade.

Neste sentido, conclui-se que, simultaneamente, estas mulheres reproduziam e contestavam valores e atitudes normativas relacionadas aos campos do gênero e da sexualidade. Se, de um lado, ainda não haviam se libertado de medos e pressóes sociais e tentavam se encaixar em padróes de gênero e sexualidade aceitos pela sociedade, por outro, ao praticarem futsal, assumindo seu gosto pela modalidade, enfrentavam inevitavelmente os preconceitos, mostrando tratar-se de um território que pode e deve ser ocupado por cada vez mais mulheres.

Como preconizado na literatura da área, o campo de pesquisa evidenciou, no campo do futsal, todas as características e contradiçôes da sociedade brasileira ${ }^{1}$. Em escala macrossocial, o machismo e a heteronormatividade estão ainda bastante arraigados no Brasil contemporâneo e, consequentemente, encontram-se também representados no microssistema do futsal feminino universitário, especialmente em virtude deste ser um esporte socialmente considerado masculino.

Em outras palavras, e retomando Damatta, constatou-se que a equipe de futsal feminino investigada era o palco onde se dramatizava a sociedade ${ }^{3}$. Tais dramatizaçóes, ao mesmo tempo em que, de um lado, reforçavam padróes hegemônicos de gênero e sexualidade, também possibilitavam o terreno para possíveis subversóes das normas sociais.

A despeito das muitas discriminaçóes sofridas pelas jovens mulheres que participaram deste estudo, elas não desistiram e nem pretendiam desistir da prática do futsal. É na resistência das atletas de futsal e de outras modalidades esportivas socialmente consideradas masculinas, que reside o potencial de desconstrução de padróes rígidos de gênero e sexualidade e de transformação social, por mais lentos que estes processos possam ser.

O futsal assumia tal importância na vida das participantes do estudo, que as experiências educativas vivenciadas constituíam parte de suas subjetividades: "Eu nâo seria eu sem o futsal, seria outra pessoa qualquer! O futsal faz parte da minha vida. É dele que eu tenho minhas amizades, é dele que eu tenho um convivio social, é dele que eu tenho alegria, que eu tenho energia pra tudo, sabe?"(Olívia). Como destaca John Dewey, vida, experiência e aprendizagem são inseparáveis.

\section{Agradecimentos}

Agrademos à Coordenação Ensino Superior (CAPES) a bolsa de estudos concedida à primeira autora para a realização desta pesquisa, fruto de sua dissertação de mestrado; e às atletas que generosamente participaram deste estudo. 


\begin{abstract}
"Pure prejudice! It comes with the ball!": the taboo of (homo)sexuality in a Women's Futsal Team

This study aimed to understand the educational experiences of women's futsal practitioners, focusing on issues related to gender and sexuality, since football is still a territory of men's hegemony. To this purpose it was held an ethnographic study with college athletes from a university located in Sao Paulo state, Brazil. The results showed that these women suffered a series of discriminations along their trajectories in the sport, associated with their gender expressions and sexual orientations. Given the coercive power of heteronormativity, the athletes made of homosexuality a taboo inside their team. It was concluded that these women simultaneously reproduced and contested values and attitudes related to normative genders and sexualities. It was also shown that futsal assumed such importance in their lives that the experiences have become part of their subjectivities.
\end{abstract}

KEYWORDS: Heteronormativity; Gender; Women; Sports; Educational experience; Ethnography.

\title{
Referências
}

1. Daolio J. Cultura, educação física e futebol. Campinas: Editora da Unicamp; 1997.

2. Daolio J. As contradições do futebol brasileiro. In: Carrano PCR, organizador. Futebol: paixão e política. Rio de Janeiro: DP\&A; 2000. p. 29-44.

3. Damatta R. Esporte na sociedade: um ensaio sobre o futebol brasileiro. In: Damatta R, organizador. Universo do futebol: esporte e sociedade brasileira. Rio de Janeiro: Pinakotheke; 1982. p. 19-42.

4. Dicionário Houaiss. Rio de Janeiro: Editora Objetiva; 2009.

5. Larrosa-Bondía J. Notas sobre a experiência e o saber da experiência. Rev Bras Educ. 2002; 19: 20-28.

6. Dewey J. Democracia e educação: introdução à filosofia da educação. São Paulo: Nacional; 1979.

7. Teixeira A. Educação como reconstrução da experiência. In: Dewey J. Vida e educação. São Paulo: Nacional; 1959. p. $1-30$.

8. Broens MC, Andrade EB, Pilan FC. A noção de fluxo contínuo da experiência: contribuiçóes de Dewey para a ciência cognitiva. Cognitio. 2008;5:25-32.

9. Rockwell E. La experiência etnográfica: historia y cultura en los procesos educativos. Buenos Aires: Paidós; 2009.

10. Geertz C. A interpretação das culturas. Rio de Janeiro: LTC, 1989.

11. Goellner SV, Reppold Filho AR, Fraga AB, Mazo JZ, Stigger MP, Molina Neto V. Pesquisa qualitativa na educação física brasileira: marco teórico e modos de usar. Rev Educ Fís UEM. 2010;21:381-410.

12. Butler J. Problemas de gênero: feminismo e subversão da identidade. Rio de Janeiro: Civilização Brasileira; 2003.

13. Furlan CC, Santos PL dos. Futebol feminino e as barreiras do sexismo nas escolas: reflexóes acerca da invisibilidade. Motriviv. 2008;20:28-43.

14. Goellner SV. Mulheres e futebol no Brasil: entre sombras e invisibilidades. Rev Bras Educ Fís Esporte. 2005;19:143151.

15. Capitânio AM. Mulher, gênero e esporte: a análise da auto-percepção das desigualdades [dissertação]. São Paulo (SP): Universidade de São Paulo, Escola de Educação Física e Esporte; 2005.

16. Borges CNF, Lopes SM, Alves CA, Alves FP. Resiliência: uma possibilidade de adesão e permanência na prática do futebol feminino. Movimento. 2006;12:105-131.

17. Rubio K, Simóes AC. De espectadoras a protagonistas: a conquista do espaço esportivo pelas mulheres. Movimento. 1999;2:50-56.

18. Goellner SV. Mulher e esporte no Brasil: entre incentivos e interdiçôes elas fazem história. Rev Pensar Prática. 2005;8:85100.

19. Mourão L. Representação social da mulher brasileira nas atividades físico-desportivas: da segregação à democratização. Movimento. 2000;13:5-18.

20. Devide FP, Osborne R, Silva ER, Ferreira RC, Saint Clair E, Nery LCP. Estudos de gênero na educaçáo física brasileira. 
Motriz J Phys Ed. 2011;17:93-103.

21. Kessler CS. "Entra aí pra completá": narrativas de jogadoras de futsal feminino em Santa Maria - RS [dissertação]. Santa Maria (RS): Universidade Federal de Santa Maria, Centro de Ciências Sociais e Humanas; 2010.

22. Silveira R. Esporte, homossexualidade e amizade: estudo etnográfico sobre o associativismo no futsal feminino [dissertação]. Porto Alegre (RS): Universidade Federal do Rio Grande do Sul, Escola de Educação Física; 2008.

23. Knijnik JD. Femininos e masculinos no futebol brasileiro [tese]. São Paulo (SP): Universidade de São Paulo, Instituto de Psicologia; 2006.

24. Franzini F. Futebol é "coisa pra macho"? Pequeno esboço para uma história das mulheres no país do futebol. Rev Bras Hist. 2005;25:315-328.

25. Moraes EV. As mulheres também são boas de bola: histórias de vida de jogadoras baianas (1970-1990) [tese]. São Paulo (SP): Pontifícia Universidade Católica de São Paulo, Faculdade de História; 2012.

26. Dornelles PG; Molina Neto V. O ensino do futebol na escola: a perspectiva das estudantes com experiências positivas nas aulas de educação física em turmas de $5^{\mathrm{a}}$ a $7^{\mathrm{a}}$ séries. In: Kunz E, organizador. Didática da educação física 3: futebol. Ijuí: Unijuí; 2005. p. 89-132.

27. Freitas LL. de. Futebol feminino: análise dos discursos dos sujeitos envolvidos em uma competiçáo infantil entre escolas públicas em João Pessoa [dissertação]. João Pessoa (PB): Universidade Federal da Paraíba, Faculdade de Educação; 2003.

28. Miskolci R. Um saber insurgente ao Sul do Equador. Rev Periodicus. 2014;1:43-67.

ENDEREÇO

J uliana Gomes J ardim Av. Hygino Muzzi Filho, 737

Campus Universitário

17525-900 - Marília - SP - Brasil

E-mail: julianagjardim@yahoo.com.br
Submetido: 11/08/2016

1a. Revisão: 10/08/2018

2a. Revisão: 18/12/ 2018

Aceito: 24/05/2021 